\title{
Pesan Dakwah Pada Buletin Jum'at Himmah \\ IAIN Palangka Raya
}

(Content Analysis Terhadap Edisi Juli-Desember Tahun 2015).

Haryanto

SMAN 4 Palangka Raya

haryanto224@gmail.com

\begin{abstract}
Bulletin Friday Himmah as one of the media propaganda Islamiyah in the State Islamic Institute ( IAIN ) Palangkaraya and tried to convey a message of propaganda to the whole society, especially students in IAIN Palangkaraya. Content analysis method (content analisys ), with research focusing on the edition of July to December 2015. The results showed that, Bulletin Himma Friday IAIN Palangkaraya contains all categories of propaganda messages that creed, Shari'ah and Morals . Results of percentage and frequency of occurrence, the message Ahklak slightly more dominant than Sya'riah and creed . Message ahklak get the largest percentage, yaitu : 44\% more dominant discusses the character of the fellow human being ( $36.36 \%$ ), while the shari'a is $36 \%$ more dominant discusses aspects of worship ( $100 \%$ ) and the faith of $20 \%$ more dominant discusses aspects of the Faith in Allah SWT ( $100 \%$ ). Judging from the results can be seen that the percentage Bulletin Himma Friday IAIN Palangkaraya want improved ahklak or behavior for the better in the running of daily life, especially for fellow human beings
\end{abstract}

Keywords: pesan, dakwah, bulletin Jumat

\section{A. Pendahuluan}

Berdakwah dengan media cetak lebih efektif apabila misi dakwah yang disampaikan sesuai dengan sasaran pembaca. Buletin masjid merupakan dakwah bil qolam dalam bingkai jurnalistik islami. Biasanya buletin yang lazim dinamai Buletin Jum'at yang diterbitkan oleh Dewan Kemakmuran Masjid (DKM). Buletin ini diterbitakan setiap hari Jum'at (sekali seminggu atau dua minggu sekali). Para jama'ah biasanya bebas mengambil apabila sudah disediakan atau dibagiakan secara cuma-cuma. ${ }^{1}$ Buletin ini adalah sebagai salah satu media cetak saat ini yang banyak digunakan oleh seorang $d a^{\prime} i$ atau mubalig untuk menyampaikan dakwah kepada masyarakat.

\footnotetext{
${ }^{1}$ Asep Syamsul M dan Romli SIP, Jurnalistik Dakwah Visi dan Misi Dakwah Bil Qolam, Bandung: PT. Remaja Rosdakarya, 2003, cet, I. h. 103.
} 
Namun sama halnya dengan media lain pada umumnya, masing-masing buletin antara buletin yang satu dengan yang lainya, memiliki perbedaan dari segi pola pesan yang disampaikan, siapa yang menulis tulisan, dan kapan buletin itu diterbitkan, semua tergantung pada siapa yang menjadi pengelolanya. Hal ini karena masing-masing media memiliki kebijakan sendiri yang berbeda-beda dari segi pengelolaan isinya. ${ }^{2}$ Meskipun masing-masing buletin tersebut disampaikan dengan aneka cara yang berbeda, namun pada hakikatnya memiliki tujuan yang sama, yaitu untuk menyebarkan ajaran Islam kepada masyarakat.

Salah satu Buletin Jum'at yang ada di kota Palangka Raya adalah Buletin Jum'ah Himmah yang dimilki oleh Institut Agama Islam Negeri (IAIN) Palangka Raya. Buletin Jum'at Himmah IAIN Palangka Raya adalah sebagai media dakwah Islamiyah yang dimiliki Institut Agama Islam Negeri (IAIN) Palangka Raya yang terbit satu minggu sekali setiap hari Jum'at yang disebarkan ke masjidmasjid besar yang ada di kota Palangka raya. Sebagai media informasi dan media dakwah, buletin memiliki peranan dalam penyiaran Islam kepada masyarakat.

\section{B. Kajian Pustaka}

Buletin Jum'at Himmah sebagai salah satu media dakwah Islamiyah yang ada di Institut Agama Islam Negeri (IAIN) Palangka Raya dan berusaha menyampaikan pesan dakwah kepada seluruh lapisan masyarakat khususnya mahasiswa yang ada di IAIN Palangka Raya agar dapat memberikan sedikit pemahaman tentang peningkatan keagamaan, baik membahas masalah fiqih, tafsir, tasawuf, hadist, dan lain-lain. Penyampaian pesan dakwah dalam pada Buletin Jum'at Himmah ini termasuk dalam bentuk dakwah bil qolam (tulisan).

Oleh karena itu, berdasarkan pemaparan di atas pemilihan Buletin Jum'at Himmah IAIN Palangka Raya sebagai subjek dari penelitian didasarkan beberapa pertimbanagan, yaitu: Buletin Jum'at Himmah IAIN Palangka Raya mudah untuk didapatkan oleh peneliti, karena penerbitnya adalah LP2M yang satu lingkungan dengan IAIN Palangka Raya. Isi pesan yang disampaikan dalam Buletin jum'at Himmah IAIN Palangka Raya lebih banyak ditulis oleh kalangan akademisi,

\footnotetext{
${ }^{2}$ Nurudin, Pengantar Komunikasi Massa, cet. II, Jakarta: PT RajaGrafindo Persada, 2007, h. 101 .
} 
berbeda halnya dengan buletin lain yang kebanyakan isi pesan yang dimuat dari masyarakat biasa. Buletin Jum'at Himmah IAIN Palangka Raya adalah salah satu buletin terbesar di Palangkaka Raya, karena penyebaran juga hampir ke setiap masjid- masjid besar, serta dikenal oleh banyak masyarakat Palangka Raya. Ruang lingkup kajian penelitian ini adalah pesan-pesan dakwah (conten analysis) dalam Buletin jum'at Himmah IAIN Palangka Raya dengan memfokuskan penelitian pada Edisi Juli-Desember Tahun 2015 dengan beberapa pertimbangan yaitu : Mempermudah peneliti dalam melakukan analisis isi (conten analysis) pesan dakwah dalam Buletin Jum'at Himmah IAIN Palangka Raya Tahun 2015, karena itu jumlahnya dibatasi. Penerbitan Buletin Jum'at Himmah IAIN Palangka Raya untuk Tahun 2015, dari bulan Januari sampai April tidak ada penerbitan.

Permasalahan yang dikaji dalam penelitian ini., adalah bagaimana kecenderungan isi pesan (conten analysis) dakwah pada Buletin Jum'at Himmah IAIN Palangka Raya Edisi Juli-Desember Tahun 2015.

\section{Metode Penelitian}

Penelitian ini menggunakan metode kuantitatif. penelitian ilmiah yang sistematis terhadap bagian-bagian dan fenomena serta hubungan-hubungannya. Tujuan penelitian kuantitatif adalah mengembangkan dan menggunakan modelmodel matematis, teori-teori dan/atau hipotesis yang berkaitan dengan fenomena alam. Proses pengukuran adalah bagian yang sentral dalam penelitian kuantitatif karena hal ini memberikan hubungan yang fundamental antara pengamatan empiris dan ekspresi matematis dari hubungan-hubungan kuantitatif. Penelitian kuantitatif banyak dipergunakan baik dalam ilmu-ilmu alam maupun ilmu-ilmu sosial, dari fisika dan biologi hingga sosiologi dan jurnalisme. Pendekatan ini juga digunakan sebagai cara untuk meneliti berbagai aspek dari pendidikan. Istilah penelitian kuantitatif sering dipergunakan dalam ilmu-ilmu sosial untuk membedakannya dengan penelitian kualitatif.

Pesan Dakwah Dalam Koran Republika (Analisis Isi Rubrik Hikmah Edisi Desember 2012), oleh Ponda Samarkandi, Subjek penelitiannya adalah rubrik Hikmah surat kabar harian Republika dan objek yang diteliti materi pesan dakwah yang disampaikan dalam rubrik hikmah. Metode yang digunakan penelitian 
deskriptif kuantitatif, yakni berupaya mendeskripsikan gejala atau fenomena dari suatu variabel yang diteliti tanpa berupaya menjelaskan hubungan-hubungan yang ada. Kedua Pelaksanaan Dakwah Islam dii Harian Sore Wawasan (Studi Analisis terhadap Rubrik Mimbar Jum'at Edisi Januari-Desember 2002) ditulis oleh Siti Muzdalifah, Hasil penelitian yang diperoleh dalam bidang akidah 19,60 \%, bidang syariah sebanyak 47,05 \% dan bidang akhlak sebanyak 33,33 \%. Hal ini juga dapat disimpulkan bahwa kebutuhan akan materi dakwah dalam bidang syariah dari para pembaca harian sore wawasan sangat besar dibanding dengan bidang akhlak dan akidah. Mengenai teknik penyajiannya, dalam menyampaikan pesan dakwah dalam rubrik mimbar jum'at menggunakan media tulisan yaitu melalui perantara surat kabar harian sore wawasan.

Penelitian ini adalah lanjutan dari penelitian sebelumnya dan membedakan dari aspek Subjek penelitiannya adalah majalah Buletin Jum'at Himmah IAIN Palangka Raya dengan objek penelitian berupa pesan dakwah pada Buletin Jum'at Himmah IAIN Palangka Raya tahun 2015 (Conten Analysis terhadap Edisi JuliDesember Tahun 2015) . Adapun metode penelitian yang digunakan adalah analisis isi dengan pendekatan kuantitatif. Selain itu, penelitian kali ini lebih mengarah kepada dakwah melalui media dengan melihat pesan-pesan dakwah dalam Buletin Jum'at Himmah IAIN Palangka Raya yang sering terbit dalam Buletin Jum'at Himmah tersebut selama tahun 2015 (Edisi Juli-Desember 2015.

Pendekatan yang dilakukan pada penelitian ini adalah penelitian analisis isi (content analysis), yang menekankan pada makna pesan teks yang manifest dalam media cetak. ${ }^{3}$ Dengan menggunakan analisis isi, peneliti dapat membandingkan berbagai simbol dalam media atau teks tertentu dan menganalisisnya dengan teknik kuantitatif. ${ }^{4}$ Analisis isi tidak dimaksudkan untuk menguji hipotesis tertentu, tetapi sekedar menggambarkan secara deskripitif aspek-aspek dan karakteristik dari pesan. ${ }^{5}$ Sedangkan dalam penelitian ini,

\footnotetext{
${ }^{3}$ Rachmat Kriyantono. Teknik Praktis Riset Komunikasi, Malang: Kencana Prenada Media Group,2009, h. 228.

${ }^{4}$ Nanang Martono, Metode Penelitian Kuantitatif: Analisis Isi dan Analisis Data Sekunder Edisi Revisi, , Jakarta: Rajawali Press, 2011, cet II h. 87.

${ }^{5}$ Eriyanto, Analisis Isi...., h. 47.
} 
menggunakan pendekatan kuantitatif. Metode yang digunakan adalah analisis isi (conten analysis). Secara umum, analisis isi berupaya mengungkap berbagai informasi di balik data yang disajikan di media atau teks. Analisis isi dapat di definisikan sebagai teknik mengumpulkan dan menganalisis isi dari suatu teks ,dalam hal ini dapat berupa kata, arti (makna), gambar, simbol, ide, tema, atau beberapa pesan yang dapat dikomunikasikan. ${ }^{6}$

\section{Pembahasan}

Merebaknya media massa dewasa ini, khususnya media cetak seperti surat kabar, tabloid, dan buletin dari era informasi dan keterbukaan, bebagai informasi tersebar setiap hari dan tiap saat, berbagai pandangan pun berkembang seakan tiada mengenal henti semua pesan dari media massa dikomsumsi oleh masyarakat serta menjadi bahan informasi dan referensi pengetahuan mereka. ${ }^{7}$ Kekuatan informasi yang disampaikan media maasa demikian hebat, sehingga aktivitas tabligh penting untuk bisa dimasukan kedalam wilayah itu, artinya para mubaligh perlu menyiapkan dirinya untuk memiliki keahlian bertabligh melalui tulisan di media massa. Setidaknya harus ada sebagian diantara mereka yang membidangi aktivitas tablighnya melalui tulisan, disamping aktivitas dibidang lainya, karena jika ini tidak diantisipasi maka dikhawatirkan masyarakat pembaca akan terbentuk oleh pesan media yang kering tanpa nilai-nilai agama. ${ }^{8}$

Dalam kamus besar bahasa Indonesia, buletin adalah media cetak yang berupa selembaran atau majalah yang berisi warta singkat atau pernyataan tertulis yang diterbitkan secara preodik oleh suatu system organisasi atau lembagalembaga untuk profesi tertentu. ${ }^{9}$ Sebagaimana halnya media komunikasi lain, buletin pun bertujuan sebagai media komunikasi antarkomunitas yang terbatas. Meskipun terbatas, sering khalayaknya cukup besar. Bahkan disebuah perusahaan holding company, audiens-nya bisa mencapai belasan ribu. Untuk menjangkau

\footnotetext{
${ }^{6}$ Nanang Martono, Metodologi Penelitian Kuantitatif,: Analisis Isi dan Analisis Data Sekunder Edisi Revisi, Jakarta: Rajawali Press, 2011, cet II, h.86.

7Jalaludin Rahmat, Retorika Modern: Sebuah Kerangka Teori Dan Praktik Berpidato, Bandung: Akademika, 1982, cet I h.269.

${ }^{8}$ Aep Kusnawan, et Al, Komunikasi dan Penyiaran Islam, Bandung: Benang Merah Press, 2004, cet I, h.24.

${ }^{9}$ Departemen Pendidikan Nasional, Kamus Besar Bahasa Indonesia, Jakarta: Balai Pustaka, 2002, edisi 3, h.174
} 
dan berkomunikasi satu sama lainya, diperlukan media komunikasi, dan buletin diterbitkan sebagai media komunikasi yang dimakssud. Sedangkan perenan buletin dalam berdakwah artinya berdakwah melalui tulisan atau buah pikir yang dituangkan melalui pena da'inya. Da'i menyampaikan pesan atau materi dakwah melalui tulisan, yang dapat disimak dan dihayati isinya oleh pembaca.

Adapun manfaat dari buletin antara lain, yakni: (1). Buletin turut mengembangkan dakwah bil qolam, buletin menjadi sarana praktek jurnalistik jama'ah sekaligus menggunakan dana umat yang diamahkan kepda masjid untuk kepentingan Islam dan jama'ah sendiri. (2). Sebagai media komunikasi dan infomasi. (3). Penerbitan buletin dapat menambah sumber dana baru bagi redaksi, yakni dengan adanya pemasukan dari iklan, misalnya toko-toko, perusahaan, tanpa mengurangi nilai religius buletin. (4). Buletin juga dapat sebagai media komunakasi mad'u. Opini mad'u, misalnya berupa surat pembaca, dapat ditampilakan. ${ }^{10}$

Buletin Masjid merupakan dakwah bil qolam dalam bingkai jurnalistik Islami. Biasanya buletin yang lazim dinamai Buletin Jum'at yang diterbitkan oleh Dewan Kemakmuran Masjid (DKM). Buletin ini diterbitakan setiap hari jum'at (sekali seminggu atau dua minggu sekali). Para jama'ah biasanya bebas mengambil apabila sudah disediakan atau dibagiakan secara cuma-cuma. ${ }^{11}$ Buletin adalah sebagai salah satu media cetak saat ini yang banyak digunakan oleh seorang $d a^{\prime} i$ atau mubalig untuk menyampaikan dakwah kepada masyarakat.(1). Buletin Jumat berfungsi sebagai media komunikasi dan informasi DKM. Melalui buletin, DKM dapat secara rutin dan transparan mengumumkan keadaan keuangan (dana zakat, infak, dan sedekah) sehingga menambah kepercayaan jamaah. (2). Pengurus DKM juga dapat menjadikan buletin sebagai media promosi (ekspose) sekaligus undangan bagi berbagai program kegiatan di lingkungan mesjid. Jadi, tidak selalu harus membuat surat undangan jika mengadakan pengajian misalnya. (3). Penerbitan buletin dapat menambah sumber dana baru bagi mesjid, yakni dengan adanya pemasukan dari iklan. Kru

\footnotetext{
${ }^{10}$ Asep Syamsul dan M.Ramli, Jurnalistik Dakwah: Visi dan Misi Dakwah Bil Qolam, Bandung: PT.Remaja Rosdakarya,2003, cet I, h.109.

${ }^{11}$ Ibid, h.103.
} 
penerbitan buletin dapat mencari iklan, misalnya toko-toko atau warung di sekitar mesjid, tanpa mengurangi nilai religius bulletin. (4). Buletin dapat juga menjadi media komunikasi jamaah. Opini jamaah, misalnya berupa surat pembaca, dapat ditampilkan. Hal ini dapat mendorong dinamika jamaah sekaligus mencapai idealisme mesjid sebagai pusat kegiatan umat Islam sebagaimana zaman Rasulullah SAW. ${ }^{12}$ Berdasarkan hasil prosentase kemunculan tema Kategorisasi pesan dakwah yang ada dalam Buletin Jum'at Himmah IAIN Palangka Raya, pesan tentang akidah menempati urutan ketiga yaitu sebesar $20 \%$ selama edisi Juli-Desember tahun 2015. Hal ini menggambarkan bahwa misi yang ingin disampaikan penulis kepada pembaca (khalayak) melalui Buletin Jum'at Himmah IAIN Palangka Raya terkait bidang akidah tidak terlalu ditonjolkan .

Hal tersebut disebabkan karena akidah adalah suatu perkara yang harus dibenarkan oleh hati dan direlasasikan dalam kehidupan kita sehari-hari. Sebab apabila seseorang dikatakan beriman, namun perbuatanya sehari-hari melanggar aturan dan ketentuan yang telah ditetapkan oleh Allah SWT maka dapat dikatakan iman tidak sempurna. Sebagaimana hadis Nabi Muhammad SAW:

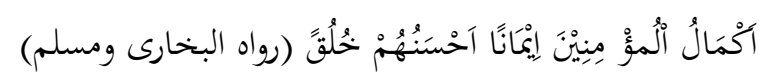

Terjemahnya:

Mukmin yang paling sempurna imannya adalah yang paling baik akhlaknya. (HR.Bukhari-Muslim). ${ }^{13}$

Oleh sebab itu, pesan dakwah bidang Akidah tidak terlalu ditonjolkan oleh para penulis dalam Buletin Jum'at Himmah IAIN Palangka Raya, akan tetapi lebih mengutamakan perubahan tinggkah laku (Akhlak) yang lebih baik, terutama dalam hubungan kita sesama manusia (hablum minannas), kemudian beribadah kepada Allah SWT. (hablum min Allah). Dengan demikian setelah memiliki akhlak dan syari'ah yang baik, maka akidah akan tertanam dengan sendirinya di dalam hati kita semua. Berikut ini adalah analisis pesan dakwah dalam Buletin

\footnotetext{
${ }^{12} \mathrm{http}: / /$ www.romelteamedia.com/2014/05/cara-membuat-buletin-jumat.html. (Diunduh: Kamis, 12 Mei 2016, Pukul 21:21 WIB)

${ }^{13}$ Hussein Bahresi, Hadits Shahih, Al-Jam'ush Shahih Bukhari Muslim, Surabaya: Karya Utama, tth. h.152.
} 
Jum'at Himmah IAIN Palangka Raya Edisi Juli-Desember Tahun 2015 yang mengandung kategori pesan akidah.

Adapun hasil penelitian dari kategori pesan akidah adalah sebagai berikut:

\section{Tabel 2}

Prosentase Hasil Penelitian Kategorisasi Pesan Akidah

\begin{tabular}{|c|c|c|c|}
\hline No. & $\begin{array}{c}\text { Kategorisasi Nilai } \\
\text { Akidah }\end{array}$ & Frekuensi & Prosentase (\%) \\
\hline 1 & $\begin{array}{l}\text { Iman kepada Allah } \\
\text { SWT. }\end{array}$ & 5 & $100 \%$ \\
\hline 2 & Iman kepada Malaikat & - & $0 \%$ \\
\hline 3 & $\begin{array}{l}\text { Iman kepada Kitab- } \\
\text { Kitab }\end{array}$ & - & $0 \%$ \\
\hline 4 & $\begin{array}{l}\text { Iman kepada Rasul- } \\
\text { Rasul }\end{array}$ & - & 0\% \\
\hline 5 & Iman kepada Hari Akhir & & $0 \%$ \\
\hline 6 & $\begin{array}{l}\text { Iman kepada Qadha- } \\
\text { Qadhar }\end{array}$ & - & $0 \%$ \\
\hline & Total & 5 & $100 \%$ \\
\hline
\end{tabular}

Sumber : Hasil Analisis

Perhitungan prosentase menggunakan rumus : $P=\frac{F}{N} \times 100$

$$
\begin{aligned}
P & =\frac{F}{N} \times 100 \\
& =\frac{5}{5} \times 100 \\
& =100
\end{aligned}
$$

Berdasarkan hasil prosentase kemunculan tema pesan dakwah yang ada dalam Buletin Jum'at Himmah IAIN Palangka Raya, pesan tentang sya'riah menempati urutan kedua yaitu sebesar 36\% selama edisi Juli-Desember tahun 2015. Hal ini menggambarkan bahwa pesan dakwah dalam Buletin Jum'at 
ISSN : $1829-8257$

IAIN Palangka Raya

Himmah IAIN Palangka Raya, bidang syariah (ibadah) merupakan langkah selanjutnya setelah perbaikan terhadap tingkah laku (akhlak) dalam kehidupan sehari-hari.

Secara harfiah, sya'riah artinya jalan, sedangkan menurut istilah keislaman, sya'riah adalah dimensi hukum atau peraturan dari ajaran islam, serta memberikan jalan atau aturan yang mengatur hubungan manusia dengan Allah SWT (hablum min Allah). ${ }^{14}$ Setelah baiknya hubungan kita sesama manusia (hablum minannas) dalam kehidupan sehari-hari. Dengan demikian terjalinnya hubungan yang baik antara manusia yang satu dengan lainnya akan mempermudah proses hubungan dengan Allah SWT. Berikut ini adalah analisis pesan dakwah dalam Buletin Jum'at Himmah IAIN Palangka Raya Edisi JuliDesember Tahun 2015 yang mengandung kategori pesan syari’ah:

Tabel 3

Kategori Pesan Sya'riah

\begin{tabular}{|c|l|c|}
\hline No & \multicolumn{1}{|c|}{ Judul } & Item \\
\hline 1 & $\begin{array}{l}\text { Ramdahan Bulan Istimewa } \\
\text { (Edisi 3 Juli 2015) }\end{array}$ & Ibadah \\
\hline 2 & $\begin{array}{l}\text { Merayakan Idul Fitri 1436 } \\
\text { (Edisi 17 Juli 2015) }\end{array}$ & Ibadah \\
\hline 3 & $\begin{array}{l}\text { Nilai Pendidikan Ramadhan } \\
\text { (Edisi 24 Juli 2015) }\end{array}$ & Ibadah \\
\hline 4 & $\begin{array}{l}\text { Mengembalikan Fungsi Masjid } \\
\text { Sebagai Pusat Pembinaan } \\
\text { Umat (Edisi 7 Agustus 2015) }\end{array}$ & Ibadah \\
\hline 5 & $\begin{array}{l}\text { Mana Yang Lebih Utama, } \\
\text { Miskin Atau Kaya ? } \\
\text { (Edisi 28 Agustus 2015) }\end{array}$ & Ibadah \\
\hline 6 & Banyak Jalan Menuju Baitullah & Ibadah \\
\hline
\end{tabular}

\footnotetext{
${ }^{14}$ Hasanuddin, Sh. Hukum Dakwah, Jakarta: Pedoman illmu Jaya, 1996, cet I, h. 44.
} 


\begin{tabular}{|c|l|c|}
\hline & (Edisi 4 September 2015) & Ibadah \\
\hline 7 & $\begin{array}{l}\text { Begadang Tanpa Hajat (Edisi } \\
\text { 11 September 2015) }\end{array}$ & Ibadah \\
\hline 8 & $\begin{array}{l}\text { Haji Mabrur } \\
\text { (Edisi 2 Oktober 2015) }\end{array}$ & Ibadah \\
\hline 9 & $\begin{array}{l}\text { Evektivitas Fungsi Masjid } \\
\text { (Edisi 11 Desember 2015) }\end{array}$ & \\
\hline
\end{tabular}

Adapun hasil penelitian dari kategori pesan syari'ah adalah sebagai berikut:

Tabel 4

Prosentase Hasil Penelitian Kategorisasi Pesan Syari’ah

\begin{tabular}{|c|c|c|c|}
\hline No & Kategorisasi & Frekuensi & Prosentase (\%) \\
\hline 1. & Ibadah & 9 & $100 \%$ \\
\hline 2. & Muamalah & 0 & $0 \%$ \\
\hline & Total & 9 & $100 \%$ \\
\hline
\end{tabular}

Perhitungan prosentase menggunakan rumus : $P=\frac{F}{N} \times 100$

$$
\begin{aligned}
P & =\frac{F}{N} \times 100 \\
& =\frac{9}{9} \times 100 \\
& =100
\end{aligned}
$$

Berdasarkan hasil prosentase kemunculan tema pesan dakwah yang ada dalam Buletin Jum'at Himmah IAIN Palangka Raya, pesan tentang akhlak menempati urutan pertama yaitu sebesar $44 \%$ selama edisi Juli-Desember tahun 2015. Hal ini menggambarkan bahwa misi yang ingin disampaikan para penulis dalam Buletin Jum'at Himmah IAIN Palangka Raya adalah tentang akhlak atau 
perbaikan terhadap tingkah laku masyarakat dalam menjalani kehidupan seharihari (hablum minannas).

Oleh Karena zaman sekarang dengan kemajuan teknologi yang semakin berkembang, nilai-nilai akhlakul karimah mulai berkurang terutama bagi anakanak kita. Dengan demikian para penulis dalam Buletin Jum'at Himmah IAIN Palangka Raya menginginkan perbaikan akhlak atau tingkah laku ke arah yang lebih baik lagi dalam menjalani kehidupan bermasyarakat terutama bagi anakanak kita sebagai generasi penerus bangsa. Berikut ini adalah analisis pesan dakwah dalam Buletin Jum'at Himmah IAIN Palangka Raya Edisi Juli-Desember Tahun 2015 yang mengandung kategori pesan akhlak:

\section{Tabel 5}

\section{Kategori Pesan Akhlak}

\begin{tabular}{|c|l|l|}
\hline No & \multicolumn{1}{|c|}{ Judul } & \multicolumn{1}{|c|}{ Item } \\
\hline 1 & $\begin{array}{l}\text { Rahasia Dibalik Kesulitan Ada } \\
\text { Kemudahan } \\
(\text { Edisi 10 Juli 2015) }\end{array}$ & $\begin{array}{l}\text { Akhlak kepada Allah } \\
\text { SWT }\end{array}$ \\
\hline 2 & $\begin{array}{l}\text { Hidup Sehat Cara Rasulullah } \\
\text { SAW } \\
\text { (Edisi 14 Agustus 2015) }\end{array}$ & $\begin{array}{l}\text { Akhlak kepada Nabi } \\
\text { Muhammad SAW }\end{array}$ \\
\hline 3 & $\begin{array}{l}\text { Meraih Surga Dengan Birrul } \\
\text { Walidaini } \\
\text { (Edisi 21 Agustus 2015) }\end{array}$ & $\begin{array}{l}\text { Akhlak terhadap sesama } \\
\text { manusia }\end{array}$ \\
\hline 4 & $\begin{array}{l}\text { Menjaga Lisan } \\
\text { (Edisi 25 September 2015) }\end{array}$ & $\begin{array}{l}\text { Akhlak terhadap sesama } \\
\text { manusia }\end{array}$ \\
\hline 5 & $\begin{array}{l}\text { Hijrah Momentum Muhasabah } \\
\text { (Edisi 9 September 2015) }\end{array}$ & $\begin{array}{l}\text { Akhlak kepada Allah } \\
\text { SWT }\end{array}$ \\
\hline 6 & $\begin{array}{l}\text { Khutbah Nabi Muhammad } \\
\text { Saw Di Padang Arafah } \\
\text { (Edisi 16 Oktober 2015) }\end{array}$ & $\begin{array}{l}\text { Akhlak terhadap sesama } \\
\text { manusia }\end{array}$ \\
\hline 7 & Surga Yang Tak Dirindukan & Akhlak terhadap alam \\
\hline
\end{tabular}




\begin{tabular}{|c|c|c|}
\hline & (Edisi 23 Oktober 2015) & \\
\hline 8 & $\begin{array}{l}\text { Istiqomah, Istikharah Dan } \\
\text { Istigfar } \\
\text { (Edisi } 30 \text { Oktober 2015) }\end{array}$ & $\begin{array}{l}\text { Akhlak kepada Allah } \\
\text { SWT }\end{array}$ \\
\hline 9 & $\begin{array}{l}\text { Kesalehan Ekologis } \\
\text { (Edisi } 6 \text { November 2015) }\end{array}$ & Akhlak terhadap alam \\
\hline 10 & $\begin{array}{l}\text { Ketika "Si Bodoh "Menerima } \\
\text { Amanat } \\
\text { (Edisi } 13 \text { November 2015) }\end{array}$ & Akhlak terhadap alam \\
\hline 11 & $\begin{array}{l}\text { Imam Masjid Sebagai Agen } \\
\text { Perubahan } \\
\text { (Edisi } 18 \text { Dedember 2015) }\end{array}$ & $\begin{array}{l}\text { Akhlak terhadap sesama } \\
\text { manusia }\end{array}$ \\
\hline
\end{tabular}

Adapun berikut ini merupakan hasil analisis penelitian dari kategori Akhlak:

Tabel 6

Prosentase Hasil Penelitian Kategorisasi Pesan Akhlak

\begin{tabular}{|c|c|c|c|}
\hline No & $\begin{array}{c}\text { Kategorisasi Pesan } \\
\text { Akhlak }\end{array}$ & Frekuensi & Prosentase (\%) \\
\hline 1. & $\begin{array}{c}\text { Akhlak kepada Allah } \\
\text { SWT }\end{array}$ & 3 & $27,27 \%$ \\
\hline $\mathbf{2 .}$ & $\begin{array}{c}\text { Akhlak kepada Nabi } \\
\text { Muhammad SAW }\end{array}$ & 1 & $9,09 \%$ \\
\hline $\mathbf{3}$ & $\begin{array}{c}\text { Akhlak kepada sesama } \\
\text { manusia }\end{array}$ & 4 & $36,36 \%$ \\
\hline $\mathbf{4}$ & Akhlak kepada alam & 3 & 27,27 \\
\hline & Total & 11 & $100 \%$ \\
& \multicolumn{2}{|c|}{} \\
\hline
\end{tabular}

Sumber: Hasil Analisis 
Perhitungan prosentase menggunakan rumus : $P=\frac{F}{N} \times 100$

- Akhlak kepada Allah SWT:

$$
\begin{aligned}
& =\frac{3}{11} \times 100 \\
& =27,27
\end{aligned}
$$

- Akhlak kepada Nabi Muhammad SAW

$$
\begin{aligned}
& =\frac{1}{11} \times 100 \\
& =9,09
\end{aligned}
$$

- Akhlak kepada sesama manusia

$$
\begin{aligned}
& =\frac{4}{11} \times 100 \\
& =36,36
\end{aligned}
$$

- Akhlak kepada alam

$$
\begin{aligned}
& =\frac{3}{11} \times 100 \\
& =27,27
\end{aligned}
$$

\section{E. Kesimpulan}

Buletin Jum'at Himmah IAIN Palangka Raya mengandung semua kategori pesan dakwah yakni Akidah, Syari'ah Dan Akhlak. Dalam pesan akidah terdapat 5 item, pesan syari'ah terdapat 9 item, dan pesan akhlak terdapat 11 item. Dilihat dari hasil prosentase dan frekuensi kemunculannya, pesan Ahklak sedikit lebih dominan dibanding Sya'riah dan akidah. Pesan ahklak mendapatkan prosentase paling besar, yatitu: sebesar $44 \%$ yang lebih dominan membahas tentang akhlak sesama manusia (36,36\%), sedangkan Syari'ah sebesar $36 \%$ yang lebih dominan membahas tentang aspek ibadah (100\%) dan akidah sebesar $20 \%$ yang lebih dominan membahas tentang aspek Iman kepada Allah SWT (100\%). Dilihat dari hasil prosentase tersebut, bahwa para penulis dalam Buletin Jum'at Himmah IAIN 
Palangka Raya menginginkan perbaikan ahklak atau tingkah laku menjadi lebih baik dalam menjalankan kehidupan sehari-hari terutama kepada sesama manusia.

\section{Daftar Pustaka}

Fethullah Gulen, Dakwah Jalan Terbaik dalam berpikir dan Menyikapi Hidup, (Jakarta : Republika, 2011). 1996).

Yusuf Qardhawy, Pengantar Kajian Islam, (Jakarta: Pustaka Al-Kautsar,

Samsul Munir Amin, Ilmu Dakwah, (Jakarta: Amzah, 2009).

Bambang Saiful Ma'arif, Komunikasi Dakwah: Paradigma Untuk Aksi, (Bandung: Remaja Rosdakarya, 2010).

Rachmat Kriyantono, Teknik Praktis Riset Komunikasi: Disertai Contoh Praktis Riset Media, Public Relations, Advertising, Komunikasi Organisasi, Komunikasi Pemasaran, Ed. Pertama, Cetakan ke-1,( Jakarta: Kencana, 2006,)

Eryanto, Ananlisis Isi: Pengantar Metodologi untuk Penelitian Ilmu Komunikasi dan Ilmu-Ilmu Sosial Lainnya, cet I,( Jakarta: Kencana, 2011).

Suharsimi Arikunto, Prosedur Penelitian: Suatu Pendekatan Praktek, (Jakarta: Rinneka Cipta, 1993).

Nur Syam, Metodologi Penelitian Dakwah: Sketsa Pemikiran Pengembangan Dakwah, (Solo: Ramadhani, 1991).

Rachmat Kriyantono. Teknik Praktis Riset Komunikasi, (Malang: Kencana Prenada Media Group.2009) .

Sutrisno Hadi, Metodologi Research II, ( Yogyakarta, YPFP UGM, 1997)

Nanang Martono, Metodologi Penelitian Kuantitatif: Analisis Isi dan Analisis Data Sekunder, (cet, ke-2, Jakarta: Rajawali Press, 2010). 